\title{
Potentiality of light source and predator for controlling brown planthopper M Sardar ${ }^{1}$, MR Khatun ${ }^{2 *}$, KS Islam ${ }^{2}$, MT Haque ${ }^{1}$, G Das $^{2}$
}

${ }^{1}$ Entomology Division, Bangladesh Institute of Nuclear Agriculture, Mymensingh 2202, Bangladesh; ${ }^{2}$ Department of Entomology, Bangladesh Agricultural University 2202, Mymensingh, Bangladesh

\begin{abstract}
Experiments were conducted at the net house and laboratory of the Entomology Division of Bangladesh Institute of Nuclear Agriculture (BINA) to determine the effectiveness of four light sources for light trapping, and performance of three predators for controlling brown plant hopper, Nilaparvata lugens (Stal.).The light intensity and sources were 30-50 lux (candle light), 80-100 lux (kerosene lamp), 180-200 lux (bulb) and 380-400 lux (energy saving lamp). The predators, ladybird beetle, carabid beetle and wolf spider, Light traps of 380-400 lux from energy saving lamp showed maximum effect in reducing the pest brown planthopper. Other light sources had little effect on brown planthopper. Light source of 30-200 lux reduced only a few brown planthopper. The predator wolf spider, Lycosa pseudoannulata consumed all the prey individuals of Nilaparvata lugens in three days exposure period indicating its high predation potentiality. Performance of ladybird beetle, Micraspis discolor was moderate and the carabid beetle, Ophionea indica was poor in controlling brown planthopper. The findings of these experiments indicate that light trapping with a source of 380-400 lux, predation by Lycosa pseudoannulata are the promising options in reducing brown planthopper population successfully and it could be an important part of IPM that is essential for the sustainable management of this deleterious brown planthopper in rice cultivation.
\end{abstract}

Key words: Rice, brown planthopper, light sources, predators, insect management

Progressive Agriculturists. All rights reserved

*Corresponding Author: rokeya.entom@bau.edu.bd

\section{Introduction}

Rice (Oryza sativa) is the most important cereal crop in the world. It is also the main staple food for more than two billion people in Asia and four hundreds of millions of people in Africa and Latin America (Anonymous, 1985). Rice covers about $74.35 \%$ of the total cropping area of Bangladesh. It is also grown throughout the year in Bangladesh. It is an ideal host for many species of insect pests. In Bangladesh, about 175 species of insect pests have been recorded on rice (Kamal, 1998). Rice suffers heavy losses every year due to attack of many pests like maize crop (Alam et al., 2019). Among them, the rice brown plant hopper, Nilaparvata lugens is wide spread and also a threat to rice production in many parts of Bangladesh. But, the brown plant hopper was formerly a minor pest in most tropical countries of Asia. Brown plant hopper, $N$. lugens became the most devastating insect pest of rice day by day in Asia due to introduce of insecticides and modern semi-dwarf rice varieties in 1960's. It has become a major problem for rice production in several parts of Bangladesh in recent years. The Brown plant hopper infests the rice crop at all stages of plant growth as like aphid of maize (Alam et al., 2018 \& 2014). Low infestation causes reduced plant height, crop vigor, tiller production, while heavy infestation turns the plants yellow which dry up rapidly. At early 
infestation, round yellow patches appear which soon turn brownish due to drying up of the plants. N. lugens is a vascular feeder and damages plants by sucking sap from the mesophyll and blocking the xylem and phloem by laying egg masses in the midribs of the leaf sheath and leaf blade. This feeding damage is commonly called "hopper burn". The patches of infestation may spread out and cover the entire field. It also acts as a vector of the virus diseases viz., grassy stunt, ragged stunt and wilted stunt (Chen and Chiu, 1981).

Insect pests are mainly controlled with synthetic insecticides over the last 50 years. But at present it is very difficult to control this insect because of injudicious uses of these chemicals this insects develop high level of resistance to almost all conventional insecticides. Beside this resistance development, conventional insecticides have negative effects on nontarget organisms, including humans and the environment. In addition to their deleterious influence on the environment, the synthetic insecticides are more hazardous to handle, toxic residues in food products, and are not easily biodegradable. All these factors are threatened for environmental sustainability (Dhillon et al., 2005). In modern agriculture people emphasis on organic food production in that perspective we should give importance on other strategies of pest control of IPM rather than chemical insecticides.

Insect light trap is one of the most effective tools for management of insect pests in organic agriculture. It is also effective method for reducing the population of insect pest as well as keeps the ecological system. The insect pests of all cereal crops, pulse crops, vegetable crops as well as horticultural crops can be mass trapped by using light traps (Holloway et al., 2001; Intachat and Woiwod, 1999). Natural enemies are often important bio-control agents of brown plant hopper in nature. More than 100 species of natural enemies of leafhoppers and plant hoppers have been reported (Dyck and Orlido, 1977). Ladybird beetle, Carabid beetle, Wolf spiders are used as bio-control agent against brown planthopper. Among various predators, Carabid beetle, Ophionea indica act as predator against brown plant hopper (Habu and Sadanaga, 1963; Wakisaka et al., 1991). The predacious coccinellid beetles, commonly known as ladybird beetles are considered to be of great economic importance in the agro-ecosystem. They have been successfully employed in the biological control of many injurious insects (Agarwala et al., 1988; Nasiruddin and Islam, 1979). Micraspis discolor species is one of the most important species of coccinellids which is found as a predator on nymphs and adults of brown plant hopper (Samal and Misra, 1985). The wolf spider, Lycosa pseudoannulata is another vital predator of brown plant hopper, and they can consume 24 nymphs or 15-20 adult hoppers per day (Samal and Misra, 1975). Application of insecticides, another method for controlling insect pest is used widely in Bangladesh. But it causes several problems such as development of insecticide resistance to pest insects, environmental pollution and undesirable effects on non-target organisms including the natural enemies of the target pests (Kiritani, 1979, Islam et al., 2015). Considering the above facts, the present study was undertaken to investigate the efficacy of four light sources as attractant, and to evaluate the performance of three common predators for controlling brown plant hopper of rice.

\section{Materials and Methods}

The experiment was conducted at the net house and laboratory of the Entomology Division, BINA, Mymensingh, Bangladesh from March to July, 2016 to evaluate the effectiveness of insecticides for controlling brown plant hopper, Nilaparvata lugens of rice. The experiment was laid out in a completely randomized design with three replications.

Collection and rearing of brown planthopper: Gravid females of brown planthopper were collected with the help of aspirator from infested rice fields of Bangladesh Agricultural University, Mymensingh. Immediately after collection, the insects were placed in 
test tube of medium size (15 cm in length). The mouth of the test tubes were then closed with pieces of fine nets and fastened with rubber bands. The collected insects were then brought to the net house of BINA and reared to build up a large population. The gravid females were immediately released on 30-40 days old rice plant of TN 1 variety grown in pots and then the pots were placed in a $0.75 \times 0.5 \times 0.2 \mathrm{~m}$ (length $\mathrm{x}$ breadth $x$ height) tray which was filled with water to one third of its height, so that the soil could not dry. The potted rice plants were covered with $0.9 \times 0.5 \mathrm{~m}$ (height $\mathrm{x}$ breadth) rearing cages. The plants were observed for egg laying every day. For a continuous supply of 30-40 days old rice plants, TN 1 seeds were sown in seed beds at an interval of 15 days regularly starting well ahead of commencement to the experiment. Then $15-$ 20 days old seedlings were transplanted in pots having $35 \mathrm{~cm}$ height and $25 \mathrm{~cm}$ diameter and containing 3.0$3.5 \mathrm{~kg}$ soil. The TN 1 plants $(3$ hills/pot were transplanted@2 seedlings/hill)were allowed to grow for 30-40 days under net house condition. The pots were kept in another same size tray filled with water as previously described. All recommended cultural practices including fertilizer and insecticide application were followed for optimum plant growth. Sevin dust, an insecticide with least residual effect was used whenever necessary to protect the brown planthopper from ants.

For egg laying purposes, adult brown planthopper was released in caged-fresh rice plants on every Sundays and Wednesdays in every week. The gravid or adult female brown planthopper was transferred from one used plant to another fresh plant with the help of an aspirator. After removal of the adults the plants were kept under the cages for a sufficient time so that the brown planthopper eggs on these plants can hatch and reach the adult or gravid stage. Moreover, before using the plants for the egg laying of brown planthopper, the outer leaf sheaths of each tiller were removed to eliminate any brown planthopper populations from the plants. After hatching of eggs, nymphs were provided with sufficient food plants for their growth and development. As soon as most of the insects from the new hatching became adults, the females and the males were transferred to another cage with fresh plants twice a week as mentioned earlier. These insects were preserved in new cages with dates of egg laying marked on them. The brown planthopper was provided with fresh plants for their food as and when necessary. In this way, brown planthopper populations of uniform age were established and within 3-4 generations, sufficient numbers of insects became available for the production of required numbers of nymphs and adults for the different experiments.

Collection and rearing of ladybird beetle: The predator, M. discolor was maintained in the net house. For this purpose adult beetles were collected from rice field of the Bangladesh Agricultural University (BAU) farm, Mymensingh. The field collected beetles were reared in plastic pot $(20 \mathrm{~cm}$ in height and $25 \mathrm{~cm}$ in diameter) covered with Mylar film cage (Mylar film cage: Hard plastic made cylindrical device). Its length is $45 \mathrm{~cm}$ and diameter $16 \mathrm{~cm}$. The upper portion of the Mylar film cage covered with nylon net. The net was attached with the cage by the help of thread). The second instars brown planthopper on 30-40 days old potted rice plants were used as food for the beetle. Mating occurred inside the Mylar film cage and the insects were allowed to lay eggs there. The eggs were separated in petridishes $(11 \times 2 \mathrm{~cm})$. After hatching of eggs, the grubs were transferred into test tube $(20 \mathrm{~cm})$. One grub was reared in each test tube providing the same food as supplied to their parents; the newly emerged adults were sexed and confined in pairs in test tube for mating and laying eggs.

Collection and rearing of wolf spider: Some sexually mature adults of wolf spider, L. pseudoannulata and adult spider with egg sac were collected from the seed bed of the rice plot of BINA, Mymensingh by using net. Each of the collected spiders was kept immediately in test tube individually. Since, the spiders are strongly cannibalistic in nature; they were confined individually in $15 \mathrm{~cm} \times 7 \mathrm{~cm}$ glass pot. They were supplied with 
different stages of brown planthopper as prey on one or two $12 \mathrm{~cm}$ long rice stem wrapped with wet cotton in the pot. All of the spiderlings became detached from the mother after 2-3 days of hatching. When newly hatched spiderlings were detached from her mother's back, they were transferred to another same sized pot. To minimize cannibalism, small pieces of rice straw were put inside the pots, thus giving chance to separate the spiderling from one another. Since, wolf spiders prefer to live at comparatively low temperature and shady area; they were reared in the laboratory at room temperature $\left(27 \pm 2^{\circ} \mathrm{C}\right)$. Later on the spiders were kept in Mylar film cage before using in experiments.

Collection and rearing of carabid beetle: The predator, Ophionea indica was maintained in the net house. For this purpose adult beetles were collected from rice field of the Bangladesh Agricultural University (BAU) farm, Mymensingh. The field collected beetles were reared in plastic pot $(20 \mathrm{~cm}$ in height and $25 \mathrm{~cm}$ in diameter) covered with Mylar film cage. The 2 nd instars brown planthopper on 30-40 days old potted rice plants were used as food for the beetle. Mating occurred inside the Mylar film cage and the insects were allowed to lay eggs there. The eggs were separated in petridishes $(11 \times 2 \mathrm{~cm})$. After hatching of eggs, the grubs were transferred into test tube $(20 \mathrm{~cm})$. One grub was reared in each test tube providing the same food as supplied to their parents; the newly emerged adults were sexed and confined in pairs in test tube for mating and laying eggs.

Net house screening: To manage brown planthopper using different light sources an experiment was conducted in the net house of BINA. Ten brown planthoppers were taken in a Mylar film cage and put in the net house. After evening the Mylar film cage was removed and the light sources were provided. Different lux range was used in this experiment. Lux output was measured from different light sources with the help of Digital Lux Meter and the range was 30-400. Light output was 30-50 lux (candle light), 80-100 lux (kerosene lamp), 180-200 lux (bulb) and 380-400 lux (energy saving lamp). After one hour the individuals of brown plant hopper attracted by light sources were counted. The same procedure continued in three days. The experiment was replicated three times.

To manage brown plant hopper by predators another experiment was conducted in the net house of BINA. Ten brown planthopper were taken in a Mylar film cage against one predator and put in the net house. The second instars brown planthopper were used as prey for the beetle and 4th \& 5th instars for the spider. After 24, 48 and 72 hours the consumed individuals of brown plant hopper were counted. The experiment was laid out in a completely randomized design with three replications.

Collection of data: In studying the efficacy of light sources, number of attracted brown plant hopper was recorded one hour after setting the light of different intensity. The performance of predators the consumed brown planthopper individuals were recorded at 24, 48 and 72 hours after releasing the predators in Mylar film cage.

Statistical analysis: The obtained data were statistically analyzed to find out the significance of differences among the treatments. The mean values of all parameters were evaluated and analysis of variance was performed by MSTAT-C software package and the mean differences were adjudged by Duncan Multiple Range Test (Gomez and Gomez, 1984).

\section{Results and Discussion}

The present experiment was carried out using four light sources, three predators to manage brown planthopper, $N$. lugens. The results of the experiments were presented below and discussed with the experimental findings of other published reports.

Effect of light sources on brown planthopper: The efficacies of light sources were examined in the net house of BINA in reducing brown planthopper. In each three days 380-400 lux (energy saving lamp) showed the highest efficacy in attraction of brown planthopper and 30-50 lux (candle light) showed the lowest efficacy 
in attraction of brown planthopper. In case of 380-400 lux percentage of brown planthopper attracted by light was $33.33 \%$ at 24 hours, $70 \%$ at 48 hours and $73.33 \%$ at 72 hours. In case of 30-50 lux percentage of brown planthopper attracted by light was $0 \%$ at 24 hours, $3.33 \%$ at 48 hours and $6.67 \%$ at 72 hours. In case of 80-100 lux percentage of brown planthopper attracted by light was $3.33 \%$ at 24 hours, $6.67 \%$ at 48 hours and $6.67 \%$ at 72 hours. In case of $180-200$ lux percentage of brown planthopper attracted by light was $16.67 \%$ at 24 hours, $23.33 \%$ at 48 hours and $33.33 \%$ at 72 hours that presented in Table 1. The result showed that the efficacy of light for reducing brown planthopper was energy saving lamp $>$ bulb $>$ kerosene lamp $>$ candle light.

Table 1. Mean percentage of Brown planthopper attracted by different light sources under net house condition.

\begin{tabular}{|c|c|c|c|}
\hline \multirow[t]{2}{*}{ Lux output } & \multicolumn{3}{|c|}{$\begin{array}{c}\text { Mean percentage of Brown plant hopper attracted by light } \\
\text { sources at different interval of time }\end{array}$} \\
\hline & 24 hrs & 48 hrs & 72 hrs \\
\hline 30-50 lux (Candle light) & $0.00 \mathrm{~d}$ & $3.33 \mathrm{~d}$ & $6.67 \mathrm{c}$ \\
\hline 80-100 lux (Kerosene lamp) & $3.33 \mathrm{c}$ & $6.67 \mathrm{c}$ & $6.67 \mathrm{c}$ \\
\hline 180-200 lux (Bulb) & $16.67 \mathrm{~b}$ & $23.33 \mathrm{~b}$ & $33.3 \mathrm{~b}$ \\
\hline 380-400 lux (Energy saving bulb) & $33.33 \mathrm{a}$ & $70.00 \mathrm{a}$ & $73.33 \mathrm{a}$ \\
\hline Control (dark for left one hour) & $0.00 \mathrm{~d}$ & $0.00 \mathrm{e}$ & $0.00 \mathrm{~d}$ \\
\hline Level of significant & $*$ & $*$ & $*$ \\
\hline CV (\%) & 7.64 & 8.12 & 6.35 \\
\hline LSD & 8.13 & 3.30 & 5.39 \\
\hline
\end{tabular}

In first column shows different light intensity found from different light sources, In second column, means followed by different letters are significantly different. *means at $5 \%$ level of probability.

Effect of predators on brown plant hopper: Results of predation performance of three predations on brown planthopper, $N$. lugens are presented in Table 2.

Table 2. Predation performance of three predators on Brown planthopper at different interval of time under net house condition.

\begin{tabular}{|c|c|c|c|}
\hline \multirow{2}{*}{ Name of predators } & \multicolumn{3}{|c|}{$\begin{array}{c}\text { Percentage of Brown planthopper consumed by the predator at different time } \\
\text { interval }\end{array}$} \\
\hline & 24 hrs & $48 \mathrm{hrs}$ & $72 \mathrm{hrs}$ \\
\hline Lady bird beetle & $16.67 \mathrm{~b}$ & $46.67 \mathrm{~b}$ & $76.67 \mathrm{~b}$ \\
\hline Carabid beetle & $3.33 \mathrm{c}$ & $6.67 \mathrm{c}$ & $16.67 \mathrm{c}$ \\
\hline Wolf spider & $96.67 \mathrm{a}$ & $100.0 \mathrm{a}$ & $100.0 \mathrm{a}$ \\
\hline Control & $0.0 \mathrm{~d}$ & $0.0 \mathrm{~d}$ & $0.0 \mathrm{~d}$ \\
\hline Level of significant & $*$ & $*$ & $*$ \\
\hline CV (\%) & 8.32 & 7.50 & 6.67 \\
\hline LSD & 3.31 & 6.62 & 16.15 \\
\hline
\end{tabular}

In column, means followed by different letters are significantly different. ${ }^{*}$ means at $5 \%$ level of probability. 1:10 Predator: Prey ratio was used. 
The results clearly revealed that all treated predators had significant effect on predation of brown plant hopper $N$. lugens, and the mean predation percentage of brown plant hopper were significantly different at $5 \%$ level of probability. Three predators' viz. ladybird beetle, carabid beetle and wolf spider were used for preying brown plant hopper at different time interval. Under considering the efficacy of three predators, Wolf spider gave the highest potentiality at 24 hours. It consumed $96.67 \%$ at 24 hours whereas, carabid beetle showed the lowest (3.33\%) preying performance. Similar type of trend of result was found at 48 hours and they showed similar type of significant $(\mathrm{P} \leq 0.05)$. Among predators, Wolf spider gave the highest (100\%) potentiality at 24 hours which was followed by $46.67 \%$ in Lady bird beetle whereas, Carabid beetle showed the lowest (6.67\%) preying performance. After 72 hours of treatment, ladybird beetle consumed $76.67 \%$ brown planthopper and carabid beetle consumed $16.67 \%$ brown planthopperthat presented in table 02 . The predation percentage revealed that wolf spider is highly effective for controlling brown plant hopper. The present result is in agreement with the findings of Kumar and Velusamy (1997) and Heong et al. (1989).

\section{Conclusion}

A series of experiment were carried out in the net house and laboratory of Entomology Division, Bangladesh Institute of Nuclear Agriculture (BINA), Mymensingh to determine the efficacy of four light sources, three in managing brown planthopper, $N$. lugens. Four light sources (Candle light, Energy saving lamp, Bulb, Kerosene lamp), three predators (Ladybird beetle, Carabid beetle, Wolf spider) were used in the experiment.

Light trap, environmentally sound method for detecting and killing harmful insects. This eco-friendly light trap method is considered as an alternative to pesticides control. Four types of light sources were used to determine the efficacy. Among them 380-400 lux (energy saving lamp) showed better performance on brown planthopper. The efficacy of four light sources was energy saving lamp $>$ bulb $>$ kerosene lamp $>$ candle light. So it can be concluded from the results of the present study that among four light sources energy saving lamp would be an effective medium for reducing brown planthopper.

Biological control of insect pest is a unique method, which is being practiced in many countries of the world for the control of field and orchard pest. From the present awareness of researchers, it appears that in the distant future, biological control would surely play an important in controlling pest in Bangladesh. The results of the present study indicated that among the three predators, the predator wolf spider acted as an effective biological control agent on brown planthopper. Another two predator ladybird beetle and carabid beetle also acted as biological control agents. The efficacy of three predators was wolf spider $>$ ladybird beetle $>$ carabid beetle. It is concluded from the present study that the predator wolf spider can act as an effective biological control agent for brown planthopper.

\section{References}

Agarwala BK, Das S, Senchowdhuri M (1988). Biology and food relation of Micraspis discolor an aphidophegous coccinellid in India. Journal of Aphidology, 2(1-2): 7-17.

Alam MJ, Ahmed KS, Hossen B, Mozammel H, Hoque ABMZ (2019). Storage pests of maize and their status in Bangladesh. Journal of Bioscience and Agriculture Research, 20(02): 1724-1730.

Anonymous (1985). Annual review for 1984. International Rice Research Institute, Los Banos, Philippines. 460 p.

Chen CC, Chiu RJ (1981). Rice wilted stunt in Taiwan. Intl. Rice Res. Newsl, 6(1): 13.

Dhillon MK, Sharma HC (2007). Survival and development of Campoletis chlorideae on various insect and crop hosts: implications for 
Bt-transgenic crops. Journal of Applied Entomology, 131(3): 179-185.

Dyck VA, Orlido GC (1977). Control of the brown planthopper by natural enemies and timely application of narrow spectrum insecticides in the brown planthopper. Food and Fertilizer Technology Center for the Asian and Pacific Region. Taipei, 58- $72 \mathrm{p}$.

Gomez KA, Gomez AA (1984). Statistical procedures for agricultural research (2 ${ }^{\text {nd }}$ Edition). $A n$ International Rice Research Institute Book. John Wiley and sons, New York, USA. 680p.

Habu A, Sadanaga K (1963). Illustrations for identification of larvae of the Carabidae found in cultivated fields and paddy-fields (II). Bull. National Institute of Agriculture Science, Tokyo. (C) 16: 151-179 (in Japanese with English summary).

Heong KL, Bleih S, Rubia EG (1989). Predation of Lynx spider on mirid bug and brown planthopper. Int. Rice Res. Newsl, 14(6): 33.

Holloway JD, Kibby G, Peggie D (2001). The families of Malesian moths and butterflies. Fauna Malesiana Handbook 3. Brill (Leiden, Boston, Koln).

Intachat J, Woiwod IP (1999). Trap design for monitoring moth biodiversity in tropical rainforests. Bull. Entomology Research, 89: 153-163.

Islam MA, Hossain MT, Khatun M, Hossen MS (2015a). Environmental impact assessment on frequency of pesticide use during vegetable production. Progressive Agriculture, 26: 97102.

Kamal NQ (1998). Brown planthopper, Nilaparvata lugens(Stål.). Situation in Bangladesh. A report of IPM ecology expert. DAEUNDP/FAO IPM Project, Khamarbari, Farmgate, Dhaka, Bangladesh.

Kiritani K (1979). Pest management in rice. Annual Reviewof Entomology, 24: 279-312.
Kumar MG, Velusamy R (1997). Prey preferences of commonly encountered spiders in the rice agro-ecosystem. Madras Agricultural Journal, 84(8): 481-483.

Alam MJ, Ahmed KS, Mollah MRA (2014). Survey of insect pests of maize crop and their identification in Shibganj upazilla under Bogra district. Bangladseh Journal of Seed Science and Technology, 18 (1\& amp; 2): 7377.

Alam MJ, Ahmed KS, Sultana A, Firoj SM, Hasan IM (2018). Ensure food security of Bangladesh: Analysis of post-harvest losses of maize and its pest management in stored condition. Journal of Agricultural Engineering and food technology, 5(1): 26-32.

Nasiruddin M, Islam MA (1979). Verania discolor Fab. (Coleoptera: Coccinellidae) an effective predator on different species on aphids.Bangladesh Journal of Zoology, 7(1): 69-71.

Samal P, Misra BC (1975). Spiders: The most effective natural enemies of the brown planthopper in rice. Rice Entomol. Newsl. 3:31.

Samal P, Misra, BC (1985). Morphology and biology of the carabid beetle, Ophionea indica, a predator of rice planthopper, Nilaparvata lugens (Stal.). Journal of Biological Control, 22 (1): $58-60$.

Wakisaka S, Tsukuda R, Nakasuji F (1991). Life tables of the diamondback moth, Plutella xylostella (L.) (Lepidoptera: Yponomeutidae) and effects of rainfall, temperature and host plants on survival and reproduction. Japanese Journal of Applied Entomologyand Zoology, 35: 115-122 (in Japanese with English summary). 